\title{
ZNACZENIE HERMENEUTYKI W BADANIACH NAD PRZEKEADEM. UWAG KILKA O TŁUMACZENIU WYBRANYCH WIERSZY CYPRIANA KAMILA NORWIDA NA JĘZYK FRANCUSKI
}

DOl: http://dx.doi.org/10.12775/RP.2019.004

Zarys treści: Przedmiotem analizy jest znaczenie teorii hermeneutycznej w przekładoznawstwie. W artykule zdefiniowano pojęcie hermeneutyki oraz pokrótce przedstawiono poglądy głównych jej przedstawicieli. Relację: hermeneutyka-przekład obrazuje w niniejszej pracy postawa tłumacza-interpretatora ucieleśniona przez Feliksa Konopkę, autora tłumaczenia na język francuski (1974) wybranych do analizy fragmentów poezji Cypriana Kamila Norwida.

Słowa kluczowe: hermeneutyka, interpretacja, przekład, poezja, język francuski, Cyprian Kamil Norwid

\section{Wstęp}

Naukowa teoria przekładu rodziła się w połowie XX wieku i już wtedy zdawano sobie sprawę, że, aby w pełni opisać przedmiot badań, powinno się uwzględnić inne, „sąsiadujące” z traduktologią dyscypliny, m.in. filozofię, antropologię, psychologię, neurobiologię (Bukowski, Heydel 2009: 5). Już Eugene Nida podkreślał potrzebę interdyscyplinarnego podejścia do przekładu, a dziś także np. Mary Snell-Hornby postuluje otwartość metodologiczną przekładoznawstwa, nie zważając na głosy, iż za sprawą innych nauk przedmiot badań traduktologii może zostać rozmyty. Także Teresa Tomaszkiewicz podkreśla interdyscyplinarny charakter translatoryki, używając liczby mno- 
giej w nazwie: „studia nad przekładem” (Translation Studies), co dowodzi związku przekładoznawstwa z innymi dziedzinami nauki:

(...) translatoryka staje się coraz bardziej domeną, która ma ogarnąć cały świat komunikacji interkulturowej, interpersonalnej i międzynarodowej, co czyni z niej dziedzinę coraz bardziej wieloaspektową. Wobec takiego stanu rzeczy nie możemy już więcej mówić w liczbie pojedynczej o translatoryce, ale w liczbie mnogiej o naukach dotyczących tłumaczenia. (...) Interdyscyplinarny charakter badań we współczesnym świecie jest jak najbardziej pożądany, a nauki o przekładzie z łatwością wpisują się w tę liczbę mnogą (Tomaszkiewicz 2016: 55).

Tomaszkiewicz w cytowanym powyżej artykule, zatytułowanym: Coraz bardziej interdyscyplinarny charakter badań przekładoznawczych, zajmuje się związkami przekładoznawstwa $\mathrm{z}$ badaniami językoznawczymi, choć wymienia także inne istotne dla translatoryki prądy badawcze: literackie, psychologiczne, społeczne, semiologiczne, matematyczne, informatyczne czy statystyczne (Tomaszkiewicz 2016: 55). Także odniesienie przekładoznawstwa do kognitywistyki, estetyki, religioznawstwa czy filozofii, w tym do hermeneutyki, pozwala na poszerzenie zakresu badań o przekładzie, dostrzeżenie nowych aspektów w opisie problematyki tłumaczenia oraz docenienie obecności i roli tłumacza.

Nie ulega wątpliwości, że akt przekładu jest aktem interpretacji. Już Johann Gottfried Herder utożsamiał tłumacza z interpretatorem. Niemiecki badacz wylicza ponadto, w nieprzypadkowej kolejności, kompetencje tłumacza, który powinien być jednocześnie: „filozofem, poetą i filologiem”, co z kolei prowadzi do stwierdzenia, iż dyskurs współczesnej hermeneutyki przekładu to skrzyżowanie myśli filozoficznej, poetyckiej i filologicznej (Bukowski, Heydel 2009: 28, za: Wuthenow 1969: 18.)

W celu zilustrowania roli, jaką w procesie przekładu odgrywa perspektywa hermeneutyczna, odwołam się do tłumaczenia literatury pięknej. Zdaje się bowiem, iż właśnie przekład poezji w najlepszy sposób obrazuje konieczność interpretowania tekstu wyjściowego przez tłumacza. Będą to wiersze wielkiego polskiego poety Cypriana Kamila Norwida w przekładzie na język francuski autorstwa Feliksa Konopki z 1974 roku. Wybór rzeczonego tłumaczenia nie jest przypadkowy, gdyż przekład Konopki - co postaram się poniżej udowodnić - w pełni odzwierciedla zawarty w tytule niniejszego artykułu temat. 


\section{Definicja hermeneutyki}

Etymologia słowa „hermeneutyka” wskazuje bezpośrednio na jego znaczenie i funkcje. Termin ten wywodzi się z języka greckiego i powstał w epoce antycznej - Platon używał go na określenie umiejętności objaśniania tekstu, Arystoteles zaś zatytułował tak swoje dzieło, które dotyczy zdań i wnioskowań sylogistycznych (Hartman 2009: 95). Słowo hermeneutikos znaczy 'dotyczący wyjaśniania', hermeneus oznacza 'tłumacza' (gr. ó $\mu \varepsilon \tau \alpha \varphi \rho a \sigma \tau \eta \varsigma)$ (Kopaliński

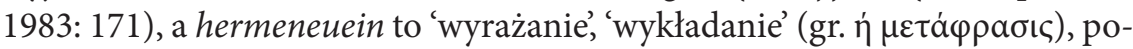
legające na interpretacji, objaśnianiu, oraz 'przekładanie' (za: Bukowski, Heydel 2009: 27). Hermeneutyka rozwijała się zwłaszcza w związku ze studiami Żydów i chrześcijan nad Torą i Ewangelią, a w renesansie - w badaniach filologicznych nad starożytnością. Ponadto obecna była w naukach prawnych oraz $\mathrm{w}$ translatoryce - odegrała znaczącą rolę w rozważaniach nad zagadnieniami przekładoznawczymi (Hartman 2009: 95). Warto także wspomnieć, że nazwa hermeneutyka pochodzi od imienia posłańca bogów w mitologii greckiej, boga podróżnych i kupców, Hermesa:

Nazwa hermeneutyki jako sztuki czynienia zrozumiałym tego, co powiedziano w obcym języku, nie bez powodu wywodzi się od imienia Hermesa, tłumaczącego ludziom boskie posłania. To etymologiczne przypomnienie nie pozostawia wątpliwości, że chodzi tu o jakieś wydarzenie językowe, o przekład z języka na język, a więc o stosunek dwóch języków (Gadamer, 2000: 135).

Można wyodrębnić różne rodzaje hermeneutyk, w tym przede wszystkim: hermeneutykę techniczną, obejmującą hermeneutykę teologiczną (wyjaśnianie Pisma Świętego) i hermeneutykę filologiczną (sztukę interpretacji każdego tekstu) oraz hermeneutykę filozoficzną (refleksję o sposobie, w jaki przebiega ludzki proces „rozumienia”) i filozofię hermeneutyczną (rozumienie jako sposób istnienia człowieka w świecie) (za: Markowski 1996: 26).

\section{Hermeneutyka a przekład}

Dla hermeneutycznej tradycji myślenia o przekładzie najistotniejszą rolę odegrali w szczególności następujący myśliciele: Friedrich Schleiermacher, Wilhelm Dilthey, Friedrich Nietzsche, Martin Heidegger, Hans-Georg Gadamer, Walter Benjamin, Paul Ricœur, Henri Meschonnic, Peeter Torop, George Steiner, Rolf Kloepfer, Fritz Paepcke, Radegundis Stolze. Nie sposób w ni- 
niejszym tekście odnieść się do wszystkich wymienionych powyżej badaczy. Przytoczę zatem jedynie istotne z punktu widzenia teorii przekładu poglądy kilku z nich: Friedricha Schleiermachera, Wilhelma Diltheya, Friedricha Nietzschego, Martina Heideggera, Hansa-Georga Gadamera i Paula Ricœura.

W tradycji filozoficznej wersję hermeneutyki uprawianej przez Schleiermachera i Diltheya zwykło się określać mianem hermeneutyki romantycznej z uwagi na głoszony przez nią postulat: „aby rozumieć autora lepiej, niż on sam mógł siebie rozumieć", co ostatecznie okazało się niemożliwe do zrealizowania (por. Ricœur 1989d: 185). Proces rozumienia opisywali oni za pomocą koła hermeneutycznego, które tworzy trójczłonowa relacja: przeżycie - ekspresja - rozumienie (Sarnowski 1985: 244). W kontekście przekładoznawczym szczególnie ważna okazała się koncepcja niezrozumiałości Schleiermachera. Niezrozumiałość i nieporozumienie są według Schleiermachera jak wskazuje J. Grondin - faktami podstawowymi, z którymi musi poradzić sobie ludzkie rozumienie (Grondin 2007: 94-95). Zatem oryginalność jego poglądów polegała szczególnie na uznaniu niezrozumiałości za fakt oczywisty, a nie za coś wyjątkowego. Schleiermacher jest także kojarzony z dwoma metodami, jakimi może posłużyć się tłumacz chcący doprowadzić do spotkania autora $\mathrm{z}$ (wirtualnym) czytelnikiem: może on albo „doprowadzić czytelnika do autora”, albo „zbliżyć autora do czytelnika” (por. Bukowski, Heydel 2009: 28). W pierwszym przypadku mamy do czynienia z egzotyzacją: tłumacz, korzystając ze swoich kompetencji, umożliwia czytelnikowi wkroczenie do (obcego) świata oryginału, $\mathrm{w}$ drugim zaś wypadku - z udomowieniem, kiedy wprowadza on autora/tekst oryginału do świata współczesnego czytelnika. Schleiermacher wybiera tę pierwszą metodę, gdyż akcentuje ona, jak wielkie znaczenie dla ojczystego języka i kultury ma spotkanie z tym, co obce (Bukowski, Heydel 2009: 28).

Natomiast Wilhelmowi Diltheyowi przypisuje się rozpowszechnienie metodologicznego rozróżnienia nauk humanistycznych od nauk przyrodniczych, które dzieli przede wszystkim cel badań. Nauki matematyczno-przyrodnicze nakierowane są na poznanie zjawisk (a zatem wyjaśnianie faktów), natomiast nauki humanistyczne - na ich rozumienie i przeżywanie, a zatem na poszukiwanie sensu (Przyłębski 1995: 38).

Z kolei Friedrich Nietzsche i Martin Heidegger pojawiają się w kontekście trzeciego rodzaju hermeneutyki wskazanej powyżej - filozofii hermeneutycznej. „Heidegger depsychologizuje rozumienie, wiążąc je ze światem” (Ricœur 1989c: 210). Rozumienie może być konceptualizowane jako sposób istnienia człowieka w świecie - staje się zatem przedmiotem ontologii, a nie epistemologii - jak było do tej pory (rozumienie jako poznawanie świata). 
Rozumienie każdego „wrzuconego w świat” Dasein jest zapośredniczone przez przedrozumienie. W Heideggerowskiej filozofii egzystencji nie ma zatem interpretacji „czystej”, nieuwikłanej w różne konteksty. Każda interpretacja jest właściwa dla konkretnego Dasein (por. Rosner 1991: 210).

Niewątpliwie jednym z najbardziej znaczących hermeneutów przekładu był Hans-Georg Gadamer, który podkreślał, że „nie czasem, lecz zawsze znaczenie tekstu wykracza poza znaczenie, jakie miał on dla swego autora. Dlatego rozumienie nie jest tylko rekonstrukcją, lecz także wytwarzaniem" (Gadamer 1993: 289). Niemiecki badacz użył metafory „stapiania się horyzontów” w kontekście opisu sytuacji „spotkania” autora z czytelnikiem, a więc także z tłumaczem. W tekście Lektura jest przekładem Gadamer podkreśla znaczenie nieprzekładalności:

(...) rozważania takie - nie nad stopniem przekładalności, lecz nad stopniem nieprzekładalności, nad tym, co tracimy, a może i nad tym, co zyskujemy w przekładzie - to temat hermeneutyczny. Nawet jeżeli przekład wydaje się przedsięwzięciem beznadziejnie deficytowym, w grę wchodzi nie tylko większa czy mniejsza strata, ale także pewien zysk, przynajmniej zysk interpretacyjny, przyrost wyrazistości i jednoznaczności (Gadamer 2009: 321).

Gadamer definiuje przekład w sposób szeroki: zarówno jako czytanie, jak i tłumaczenie właściwe, gdyż w obu przypadkach dochodzi do tego samego aktu hermeneutycznego: „transpozycji w inne medium” (Bukowski, Heydel 2009: 29). Zatem: „każdy czytelnik jest jak tłumacz” (Gadamer 2009: 324). Zgodnie ze słowami Gadamera:

Literatura stała się literaturą dzięki upowszechnieniu kultury czytelniczej. Należałoby niemal powiedzieć: literatura to literatura przekładowa, właśnie dlatego, że jest kulturą czytania. Faktycznie tajemnica czytania jest niczym most rozpięty między językami. Na całkiem różnych poziomach wydaje się tym samym aktem hermeneutycznym. Już czytanie tekstów we własnym, ojczystym języku jest poniekąd przekładem, prawie jak przekład na obcy język, jest transpozycją w inne medium - medium dźwięków i strumienia mowy. Czytanie jest nie tylko rozumieniem, ale i wykładnią - przy zwykłym czytaniu tekstów oryginalnych albo tłumaczeń wykładnią, która zawiera się w tonacji i tempie, modulacji i artykulacji „wewnętrznego głosu” kierowanego do „wewnętrznego ucha”, przy faktycznym tłumaczeniu z obcego języka ponadto wykładnią składającą sens i brzmienie w nową całość tekstu. W obu wypadkach jest transpozycją graniczącą z aktem twórczym (Gadamer 2009: 324). 
Natomiast Paul Ricœur, uznawany za najważniejszego obok Heideggera i Gadamera przedstawiciela współczesnej hermeneutyki filozoficznej, pojmował tę dyscyplinę najpierw jako interpretację symboli i mitów (we wcześniejszym okresie twórczości), a następnie jako interpretację tekstu (w późniejszym okresie twórczości). W procesie przekładu francuski myśliciel akcentuje inność i dystans. Tekst stanowi więc, jego zdaniem, przykład komunikowania się na dystans, „przyswojenia” niesionego przez tekst sensu (por. Ricœur 1989b: 272-289). Francuski filozof podkreśla historyczny wymiar ludzkiego doświadczenia (por. Bukowski 2009: 358). Jest to komunikacja oddalonych od siebie obcych, którzy osadzeni są w odmiennym czasie i miejscu. Nie ma możliwości pełnego „stopienia horyzontów świata autora i czytelnika, a więc także tłumacza", gdyż wszystko ich dzieli: sytuacja historyczna, życiowa, określone upodobania, poglądy, oczekiwania. Ricœur podziela zdanie Gadamera, iż nie sposób „powiesić na kołku” własnych przedsądów i hipotez, i niejako jak tabula rasa przystąpić do lektury czy też przekładu tekstu. Każdy czytelnik ma pewne wyobrażenie o tekście, pewne oczekiwania względem jego treści, które weryfikuje w trakcie lektury. Wyraża to także Ricœurowska formuła koła hermeneutycznego: „aby zrozumieć, należy uwierzyć, zaś aby uwierzyć, należy rozumieć". Tekst coś znaczy tylko wtedy, kiedy czytelnik przenosi go do własnej sytuacji życiowej, kiedy nabiera on znaczenia dla niego samego. W pewnym sensie czytelnik - a za Gadamerem powiemy: także tłumacz współtworzy sens tekstu, który jako autonomiczny twór aktywuje niesiony przez siebie sens wraz z nabieraniem znaczenia dla jednostkowego jestestwa. Pozbawiony „wsparcia” ze strony swego autora, tekst „ożywa” jedynie na skutek konkretnej interpretacji zakorzenionej w kontekście - powtórzmy to raz jeszcze - w określonym czasie i miejscu właściwym dla jego odbiorcy.

\section{Tłumacz to interpretator na przykładzie przekładu wierszy C. K. Norwida}

Biorąc pod uwagę przedstawione powyżej poglądy przedstawicieli hermeneutyki, nie można mieć wątpliwości, że tłumacz - jak każdy czytelnik - ma zawsze określoną wizję tłumaczonego tekstu, „patrzy na niego” z pewnej perspektywy. Jest to naturalny stan rzeczy. Każde tłumaczenie stanowi interpretację przekładanego tekstu. Zgodnie $\mathrm{z}$ teorią hermeneutyczną tłumacz zostaje więc utożsamiony z interpretatorem, który nie może „pozbyć się" swoich przedsądów. Ma on zatem prawo do własnej interpretacji tekstu. Istotnym jednak pytaniem jest, jak daleko może on „interpretować, w znaczeniu: „od- 
dalać się” od tekstu wyjściowego. Gdzie są granice „wolności tłumacza”, a co za tym idzie - jego „kreacji”? Pozostawiam na razie to pytanie w zawieszeniu, gdyż - jak się zdaje - nie ma na nie jednoznacznej odpowiedzi. Można jedynie próbować wskazywać „momenty” indywidualnych interpretacji w konkretnych aktach przekładu i - po zgromadzeniu odpowiedniej ilości przykładów - wyciągać znaczące wnioski. Parafrazując bowiem słowa Ricœura: nie ma jednej „obiektywnie” najlepszej interpretacji tekstu - podobnie jak w przypadku „walczących ze sobą" hermeneutyk - a tylko ta, która okaże się „najlepsza” w danym momencie i okolicznościach. „Zwycięża” dlatego, że zostaje uznana za najbardziej adekwatną, zważywszy cel i odbiorcę przekładu. Także Stolze wypowiada się na temat „wolności tłumacza” i stwierdza:

Cóż jednak miałaby ona oznaczać? Często, choć nie zawsze wprost, mówi się o tzw. tłumaczeniu wolnym, czyli takim, które odbiega od dosłownego brzmienia oryginału. Tradycyjnie zwykło się wszak przyjmować, że tłumaczenie winno być „tak wierne, jak tylko się da, i tak swobodne, jak jest to konieczne” (Stolze 2009: 354).

W celu zobrazowania cytowanych powyżej słów Gadamera w niniejszym artykule odnoszę się do poezji Cypriana Kamila Norwida (1821-1883) ${ }^{1}$ w przekładzie na język francuski². Wybór tłumaczenia wierszy właśnie tego poety nie jest przypadkowy z wielu powodów. Przede wszystkim dlatego, że - jak się okaże, tłumaczenie jego wierszy autorstwa Feliksa Konopki odzwierciedli główne założenie artykułu - przekład jest aktem interpretacji. Ponadto na wyborze

${ }^{1}$ W Polsce twórczość C. K. Norwida cieszy się wciąż żywym zainteresowaniem. Nie sposób wymienić wszystkich publikacji na jej temat. Na pewno warto wspomnieć o prof. Jadwidze Puzyninie i założonej przez uczoną Pracowni Słownika Języka Cypriana Norwida, a także o kilku publikacjach J. Puzyniny na temat poezji Norwida: Studia nad językiem Cypriana Norwida, pr. zb. (red.), UW, Warszawa 1990; Słowo Norwida, Zakład Narodowy im. Ossolińskich, Wrocław 1990; Słowo poety, UW, Warszawa 2006. Również w Wydawnictwie Naukowym Uniwersytetu Mikołaja Kopernika w Toruniu wydanych zostało kilka książek poświęconych twórczości Norwida, m. in. G. Halkiewicz-Sojak, 2010, Nawiązane ogniwo. Studia o poezji Cypriana Norwida i jej kontekstach, Toruń; D. Pniewski (red.), 2012, Jedno dzieło - wiele interpretacji. Rozważania nad „Wielkimi słowami" Cypriana Norwida, Toruń.

${ }^{2}$ O przekładach poezji Norwidowskiej na języki obce zob. m.in. J. Puzynina, B. Subko, 1998, „Les traductions françaises de la poésie de Cyprian Norwid”, [w:] La littérature polonaise en France, M. Laurent en la collab. avec L. Dyèvre (red.), Lille, s. 151-164; O. Płaszczewska, Włoskie przekłady poezji Norwida, „Studia Norwidiana”, 36, https://ruj.uj.edu.pl/xmlui/bitstream/handle/ item/61425/plaszczewska_wloskie_przeklady_poezji_norwida_2018.pdf?sequence=1\&isAllowed=y (dostęp: 10.02.2019); J. Scholz, 1999-2000, Nowy przekład Norwida na język niemiecki, „Studia Norwidiana”, 17-18, s. 363-373; A. Brajerska-Mazur, 2004, Norwid w tłumaczeniach Jerzego Pietrkiewicza, „Pamiętnik Literacki”, 95/1, s. 151-174. 
poezji właśnie Norwida zaważyła biografia poety odzwierciedlająca jego poczucie obcości, inności i dystansu do otaczającej go rzeczywistości: niełatwe życie na emigracji i niezrozumienie twórczości poety za jego życia. Norwid opuszcza Polskę w 1842 roku, przebywa najpierw w Niemczech, we Włoszech, w Anglii, a następnie spędza trzydzieści lat w Paryżu. Fiaskiem kończy się jego próba ucieczki do Stanów Zjednoczonych. W Paryżu żyje w biedzie, w ostatnich latach życia mieszka w przytułku dla polskich starców, zostaje pochowany w zbiorowej polskiej mogile w Montmorency (Wyka 1974: 6).

Autorem prezentowanego w artykule przekładu zbioru wierszy Norwida na język francuski jest Feliks Konopka (1888-1982). Jak już wspomniałam we Wstępie, był on polskim poetą i malarzem, uczącym się zawodu u samego Jacka Malczewskiego; autorem czterech tomików poezji: Słowa w ciemności, Ostatnia jesień, Et ne nos inducas... i Skarbonki z rudej gliny; tłumaczem literatury niemieckiej i francuskiej na język polski, w tym Fausta J. W. Goethego, Lotty w Weimarze T. Manna, Listów do Mileny F. Kafki oraz wierszy P. Verlaine’a. Oprócz poezji Norwida, przełożył także z języka polskiego na francuski m.in. Zemstę A. Fredry i Sonety krymskie A. Mickiewicza (zob. Feliks Konopka w rocznicęśmierci).

Wybrane do analizy fragmenty pochodzą z następujących wierszy Norwida w przekładzie autorstwa Feliksa Konopki z 1974 roku: Sfinks [II], Pamiętał wszystkie dawne znajomości, Na posadzkę zapustnej sceny, Fatum i Czułość (Norwid 1974).

Niewątpliwie twórczość Norwida nie należy do najłatwiejszych. Tłumacz jego wierszy ma zatem trudne zadanie do wykonania, część poezji Norwida osadzona jest bowiem w tematyce typowo polskiej, patriotycznej, w kraju pozbawionym niepodległości. Mimo że poeta starał się, by jego wiersze zostały docenione przez współczesnych, tak się niestety nie stało. Kazimierz Wyka pisze: „Działalności twórczej Norwida towarzyszyło całkowite niezrozumienie ze strony współczesnych i daremny przeciwko temu bunt artysty. Rzeczywista kariera Norwida rozpoczęła się poza epoką, w której żył” (Wyka 1974: 6). Norwid - jak stwierdza Wyka - „wychylał się poza swoją epokę ku przyszłości” (Wyka 1974: 8) oraz „(...) gorzki i stoicki wobec współczesnych, pewien był tego, że przyszłość oceni jego poezję" (Wyka 1974: 10). Poeta nie mylił się w tych przypuszczeniach, zapisując przysłowiowe już dziś słowa: „syn - minie pismo, lecz ty spomnisz, wnuku”, czy też: „współczesność minie niestateczna, lecz nie ominie Przyszłość: Korektorka - wieczna! ..." (za: Wyka 1974: 10). 
Poniżej cytuję wybrane fragmenty poezji Norwida w przekładzie na język francuski autorstwa wspomnianego już powyżej F. Konopki (Norwid 1974). Wytłuszczone przeze mnie słowa i wyrażenia, które są przykładami dokonanej przez tłumacza interpretacji tekstu oryginalnego, będą przedmiotem omówienia zamieszczonego pod każdym cytowanym wierszem bądź jego fragmentem.

\section{Sfinks [II]}

Zastąił mi raz Sfinks u ciemnej skały,

Gdzie jak zbójca, celnik lub człowiek biedny, „P r a w d!” - wołając, wciąż prawd zgłodniały,

Nie dawa gościom tchu.

- „C złowiek?...-jest to kapłan bez-wiedny

I niedojrzały ..."-

Odpowiedziałem mu.

Alić - o! dziwy...

Sfinks się cofnął grzbietem do skały:

- Przemknąłem żywy!

Le Sphinx [II]

Il advint une fois qu'au pied d'un noir rocher,

Où tel un douanier, bandit ou mendiant,

Quêtant des vér i t é s à titre de péage,

Le Sphinx en sentinelle arrête les passants -

Il advint que le Sphinx, me voyant approcher,

A mon tour me barra le passage.

- „L'h o m m e?... - L'h o m m e e st u n p rêtr e”, ainsi lui répondis-je, „Un prêtreinconscient,et bien lent à mûrir...”

Sur quoi, le Sphinx - ô prodige! -

Dos au rocher soudain de se tapir,

Cédant d'une semelle.

-Tandis que sûr de mon gain

Je me remis en chemin

Léchappant belle 
Porównując tekst oryginalny $\mathrm{z}$ przekładem, $\mathrm{w}$ tłumaczeniu wiersza Sfinks na język francuski dostrzega się od razu różnicę w długości dzieła wersja francuska została wydłużona. W oryginale w pierwszej zwrotce są cztery wersy, a w przekładzie na język francuski - sześć wersów. Natomiast $\mathrm{w}$ drugiej zwrotce w oryginale są trzy wersy, w przekładzie - dwa wydłużone. Największą innowację stanowi jednak zwrotka trzecia, w której w oryginale są trzy wersy, a w przekładzie dwa razy więcej, czyli - sześć. W poczynionych przez tłumacza zmianach w strukturze dzieła dostrzec można jedną $\mathrm{z}$ tendencji deformujących wymienionych przez Antoine'a Bermana w eseju zatytułowanym Przekład jako doświadczenie obcego (La traduction comme épreuve de l'étranger): wydłużanie tekstu przekładu. Efektem takiego zabiegu jest „nadtłumaczenie” tekstu, które zniekształca oryginał i zaburza „przebieg rytmiczny utworu" (Berman 2009: 256).

Ponadto tłumacz, Feliks Konopka, zdaje się, sam będąc poetą, pisać ten wiersz od nowa. Gdzie indziej kładzie nacisk i akcent. W pierwszej zwrotce przedłuża opis sceny „spotkania ze Sfinksem”. Dubluje w nieco zmienionej formie zdanie pierwsze i zamieszcza je raz jeszcze w wersie piątym: „Il advint que le Sphinx, me voyant approcher”. Pojawiają się też, nieobecne w oryginale, powtórzenia wyrazów: l'homme, un prêtre i le Sphinx oraz zostają dodane dwa wersy: „Tandis que sûr de mon gain/Je me remis en chemin”. Konopka, dokonując tych odstępstw od wersji wyjściowej, które nie wydają się zwykłymi przeoczeniami, zmienia wydźwięk tłumaczonego tekstu.

\section{II. [PAMIĘTAŁ WSZYSTKIE DAWNE ZNAJOMOŚCI]}

Pamiętał wszystkie dawne znajomości

Prócz siebie, kobiet kilku i młodości!...

\section{[LUI, IL SE RAPPELAIT SES VIEILLES CONNAISSANCES]}

Lui, il se rappelait ses vieilles connaissances

Sauf quelques cours, lui-même et son adolescence!...

Już w tytule wiersza, a także w pierwszym wersie, widoczna jest interpretacja tłumacza. W oryginale tytuł brzmi: „Pamiętał wszystkie dawne znajomości”, w przekładzie zaś zostaje pominięte słowo: „wszystkie”, a wprowadzony zaimek przymiotny dzierżawczy: ses („swoje”, „jego"): „Pamiętał swoje dawne znajomości". Użycie metonimii w przekładzie francuskim: quelques cours (dosł. kilka serc) w miejsce: „kobiet kilka” oraz dwukrotnie - w tym także w tytule - zaimka akcentowanego (fr. le pronom tonique): lui w celu położenia nacisku na podmiot liryczny, w moim przekonaniu, nie było intencją Norwida. Natomiast 
tłumacz „uszlachetnił” tekst oryginału poprzez „poetyzację": umieszczenie we francuskim przekładzie figur retorycznych (por. Berman 2009: 256).

\section{III. [NA POSADZKĘ ZAPUSTNEJ SCENY]}

Otworzyłem okno z drżeniem szkła,

Że aż gmachem moja wstrząsnęła siła,

Z kandelabrów spadła jedna łza - -

- ale i ta jedna - z w o s k u b yła! ...

[SUR UN PARQUET DE MI-CARÊME]

J'entrouvris la fenêtre en un cruel vacarme,

Au point que l'édifice en tout dut en frémir,

D’un candélabre alors séchappa une larme - -

- Mais cette larme, hélas! N'était faite qu' e n c i r e !...

Dodany w przekładzie przymiotnik cruel oznaczający w tym kontekście: coś nieznośnego, dotkliwego wzmacnia jeszcze znaczenie francuskiego rzeczownika un vacarme (ogłuszajacy hałas). Niewątpliwie jest to interpretacja i dopowiedzenie tłumacza. Ponadto Konopka powtarza zwrot: cette larme. Takiego powtórzenia nie ma $\mathrm{w}$ oryginale. Poza tym dodaje słowa: alors (wtedy) i hélas (niestety), co może już być uznane za pewną nadinterpretację tekstu, a na pewno za wzmocnienie jego sensu. W tłumaczeniu pojawia się też konstrukcja ne ... que odpowiadająca polskiemu przysłówkowi: tylko, podczas gdy wystarczyło we francuskim przekładzie, zgodnie $\mathrm{z}$ literą wiersza Norwida, napisać: était faite en cire. Także w tym przypadku pojawia się wyodrębniona przez Bermana deformacja negatywna: objaśnianie (Berman 2009: 254-255). O tej tendencji deformującej pisze też Tomaszkiewicz, nazywając ją wyjaśnieniem i doprecyzowaniem sensu (Tomaszkiewicz 2016: 105). Tymczasem zdaje się, że Norwid nie chciał tego sensu wyrazić wprost, a raczej domyślnie. Interpretacja tłumacza idzie także w kierunku wartościowania opisywanej w wierszu sytuacji. Konopka kieruje uwagę czytelnika na zawiedzioną nadzieję podmiotu lirycznego: „łza (niestety) też była z wosku”.

\section{FATUM}

I

Jak dziki zwierz przyszło N i e s z c z ę ś c i e do człowieka

I zatopiło weń śmiertelne oczy...

- Czeka - -

Czy, człowiek, zboczy? 
II

Lecz on odejrzał mu, jak gdy artysta

Mierzy swojego kształt modelu;

I spostrzegło, że on patrzy - c o? skorzysta

Na swym nieprzyjacielu:

I zachwiało się całą postaci wagą

- - I nie ma go!

FATUM

$I$

Menaçant et cruel, grondant comme une bête,

Le $\mathrm{M}$ a $\mathrm{l}$ h e u r vint à l'homme et brutal se carra...

- Il guette - -

Si l'homme obliquera?

II

Mais l'homme le toisa de ce regard sévère

Dont l'artiste contemple un nu; et ce voyant

Le Malheur s'aperçut qu'il cherchait seulement

Q u e l p r of i t il pourrait tirer de l'adversaire...

Et du coup sébranlant - ô prodige inouii! -

Le Malheur chancela, pâlit, s'évanouit.

W Fatum czytelnik znajdzie przykład zmiany nie tylko formy, ale i treści wiersza, podczas gdy język francuski pozwala na dokładne oddanie sensu i formy oryginału. W tłumaczeniu powstaje odmienny w stosunku do pierwowzoru obraz tytułowego Fatum (przeznaczenia, losu), w tym przypadku: złego losu - Nieszczęścia. Nieszczęście w oryginale jest ożywione (animizacja): patrzy (Norwid używa rzeczownika: oczy). Jest porównywane do „dzikiego zwierza”. Nieszczęście pojawiło się i „czeka” na reakcję człowieka. Zaś we francuskiej wersji Nieszczęście się rozsiada (fr. se carrer - 'rozsiadać się,' 'układać się wygodnie'). Mamy tu do czynienia z inną konceptualizacją Nieszczęścia. Może to być zwykłe przeoczenie, które jednak ma znaczenie dla interpretacji tekstu. Brak w tekście francuskim, w pierwszej zwrotce, nawiązania do „oczu” jest zubożeniem jakościowym tekstu oryginalnego (por. Berman 2009: 257). Z oczu można wyczytać całą prawdę o człowieku i analogicznie w tym przypadku - o Fatum. To „mierzenie się" wzrokiem przywołuje walkę na ringu, gdzie przeciwnicy starają się jeden drugiego „przestraszyć”, „Zastraszyć”, by mieć nad tą drugą osobą już od początku przewagę. 
Ponadto w ostatnim wersie oryginału akcja jest wartka, tzn. czytelnik „czuje”, że Nieszczęście znika szybko, nagle, niepostrzeżenie, jakby było zdziwione reakcją człowieka: „I nie ma go”. Poza tym Norwid używa specyficznego znaku graficznego: „, -"(„- - I nie ma go!”), którego brakuje w drugiej zwrotce utworu francuskiego. W oryginale wyakcentowany jest fakt zwycięstwa człowieka nad Fatum ${ }^{3}$. Człowiek „zwyciężył”, gdyż spojrzał na Nieszczęście tak, jak „artysta patrzy na swój model” - odważnie, bez strachu. Natomiast w języku francuskim dwukrotnie pojawia się nieobecny w drugiej zwrotce w oryginale rzeczownik: Nieszczęście, w tym właśnie w ostatnim wersie, gdzie Nieszczęście się chwieje/waha się, blednie i ulatnia się. W Wersji francuskiej scena znikania zostaje wydłużona w czasie, tym samym jest to inny obraz niż w oryginale. Ma to znaczące konsekwencje, francuski odbiorca otrzymuje bowiem odmienną od pierwotnej wizję tej sceny.

\section{CZUŁOŚĆ}

Czułość - bywa jak pełny wojen krzyk,

I jak szemrzących źródeł prąd,

I jako wtór pogrzebny...

I jak plecionka długa z włosów blond,

Na której wdowiec nosić zwykł

Zegarek srebrny ...

\section{TENDRESSE}

La tendresse est parfois comme un cri rauque et long

Et comme d'une source un aveu haletant

Ou tel un glas urgent...

Ou parfois tel un long cordon de cheveux blonds

Auquel le veuf a soin de porter en suspens

Une monter en argent ...

W zacytowanym powyżej fragmencie tłumaczenia wiersza Czułość odnotować można dodanie przez tłumacza kilku słów, których nie ma w oryginale: przymiotników long (długi) i urgent (nagły), przysłówka parfois (czasem) i wyrażenia en suspens ( $w$ zawieszeniu, w niepewności). W drugim wersie Konopka używa rzeczownika un aveu znaczącego po polsku: wyzwa-

${ }^{3}$ Interpretacji wiersza Fatum Norwida dokonał m.in. Z. J. Nowak 1991-1992.

${ }^{4}$ Zob. też analiza J. Puzyniny na temat przekładu „Fortepianu Szopena” na język francuski (J. Puzynina, B. Subko 1998). 
nie, przyznanie się, a także literacko: zgodę, zezwolenie. Jest to kolejna zmiana znaczenia dokonana przez tłumacza wobec oryginału, w którym Norwid pisze o „prądzie szemrzących źródel” (fr. courant - pl. 'prąd'), a nie o wyznaniu czy też przyznawaniu się do czegoś.

Wskazane powyżej przykłady interpretacji polskiego wiersza przez tłumacza potwierdzają obecność w procesie tłumaczenia następujących technik: wyjaśniania czegoś wyrażonego w tekście wyjściowym w sposób domyślny; konkretyzowania i doprecyzowywania sensu/obrazu z tekstu oryginalnego oraz używania/nadużywania powtórzeń, które również wpływają na „rozjaśnianie” treści pierwotnej (zob. Tomaszkiewicz 2016: 105). Berman wszelkie „uzupełnienia” wersji wyjściowej nazywa „objaśnianiem”. Jest to strategia translatorska, która stanowi konsekwencję racjonalizacji (por. Berman 2009: 254-255). Dzieje się tak w sytuacji, gdy w oryginale język celowo zostaje użyty w sposób „nieokreślony”, „ciemny”, w przekładzie zaś tłumacz dąży do „narzucenia” "określoności”, „jasności” słowom lub sensowi (zob. Wesołowska 2014: 462). Wydaje się jednak po raz kolejny (por. przedstawioną powyżej analizę wiersza „Na posadzkę zapustnej sceny”), że taki zabieg przekładowy nie jest pożądany, jeśli bowiem autor oryginału „skrywał” sens, starał się, żeby był on „stłumiony”, „niewidoczny”, to tłumacz również powinien starać się "zbudować” taki sam obraz w przekładzie (Berman 2009: 254-255), a nie czynić „jasnym” coś, co w zamierzeniu miało pozostać „ukryte”, „niedopowiedziane" (por. Wesołowska 2014: 462-463).

\section{Zakończenie}

W niniejszym artykule starałam się udowodnić, że związek hermeneutyki, definiowanej jako teoria interpretacji, z przekładem nie ulega wątpliwości. Hermeneutyka zawiera w sobie pewną „teorię" przekładu, natomiast każdy przekład jest wydarzeniem hermeneutycznym - nie sposób więc określić, czy przekład jest metaforą hermeneutyki, czy hermeneutyka - przekładu (Skrendo 2010: 4). Tematem hermeneutycznym nie są podobieństwa między oryginałem a przekładem, ale różnica między rzeczonymi tekstami. Zatem inność, obcość, dystans zawsze będą obecne w przekładzie.

Celem niniejszej pracy nie była szczegółowa analiza tłumaczenia wybranych wierszy Norwida autorstwa Konopki. Moim zamiarem nie było ocenianie przekładu francuskiego w kategoriach ścisłości i wierności względem oryginału, czy też wskazywanie błędów w tłumaczeniu (por. Wesołowska 2014: 
455-456). Chodziło o dostrzeżenie, że niektóre decyzje tłumacza są zależne od rozumienia przez niego tekstu wyjściowego. Trafnie ujął to Gadamer:

I temu wszystkiemu sprostać ma tłumacz! Chciałoby się odnieść do niego dowcipne powiedzonko Friedricha Schlegla o rozumiejącym czytelniku, interpretatorze. „Aby kogoś zrozumieć, trzeba najpierw być od niego mądrzejszym, a potem równie mądrym oraz równie głupim jak on. Nie wystarczy, że właściwy sens mętnego dzieła zrozumiemy lepiej, niż rozumiał je autor. Trzeba umieć też samą mętność rozpoznać aż po jej zasady, scharakteryzować i skonstruować" (Schlegel 1956: 58). To ostatnie jest najtrudniejsze. Ryzykujemy, że wyjdziemy na większych głupców niż tamten, jeśli chcemy na podstawie własnych szerszych horyzontów i przenikliwszego spojrzenia przekonująco wypowiedzieć sens przeczytanego tekstu (Gadamer 2009: 322).

Co stanie się jednak, gdy tłumacz nie sprosta wyzwaniu stawianemu przez oryginał, gdy nie podoła temu zadaniu? Czy należy od razu przekreślić, odrzucić jego pracę? Nie sposób jednoznacznie odpowiedzieć na te pytania. Niewątpliwie nie do przecenienia jest krytyka przekładu - konieczna i wartościowa w kontekście ciągłego ulepszania warsztatu tłumacza. Biorąc pod uwagę fakt, iż każda interpretacja tekstu jest względna i nieostateczna, można ją podejmować wciąż na nowo. Jest to zadanie, które stoi przed czytelnikiem, a jego wynik nigdy nie jest znany, nie można go przewidzieć. Zgodnie ze słowami Ricœura: „tekst pośredniczy w naszym rozumieniu siebie”, a wraz z pojawieniem się „subiektywnego czytelnika”

uwidacznia się w nim podstawowa cecha wszelkiego dyskursu, jego skierowanie ku komuś. Jednakże w odróżnieniu od dialogu ten ktoś nie jest tutaj dany przez sytuację dyskursu: jest on, jeśli tak można powiedzieć, stworzony przez samo dzieło. Dzieło wyznacza swych czytelników i w ten sposób stwarza swego subiektywnego adresata (Ricœur 1989a: 242).

W związku z tym, że - jak już pisałam na wstępie analizy - nie sposób dotrzeć do intencji autora tekstu, pozostaje zatem sam tekst i jego przesłanie. Sens tekstu ma być dopowiedziany przez czytelnika, umieszczony w jego sytuacji egzystencjalnej. Stolze podkreśla, że tłumacz jest twórczym czytelnikiem, a zatem „w tłumaczeniu za sprawą kreatywnych rozwiązań pogłębione zostaje rozumienie tekstu”, a samo „tłumaczenie, pojmowane jako ciągły proces, jest zatem wciąż naszym projektem hermeneutycznym” (Stolze 2009: 352). Niemiecka badaczka - o czym pisałam już powyżej, rozpoczynając analizę wybranych wierszy Norwida - postuluje „wolność tłumacza” i wyjaśnia, że często w naszych ocenach przekładu 
mylimy wyrażenie językowe z myślową treścią, wskutek czego tłumaczenie sprowadzone zostaje do przekodowania znaków językowych. Ze względu na różnorodność struktur poszczególnych języków tzw. tłumaczenie dosłowne prawie nigdy nie jest możliwe. Tłumacze usiłują raczej „nadrobić” utracony sens oryginału, korzystając z możliwości, jakie oferuje im język docelowy (Stolze 2009: 354).

Zatem koncepcja „tłumaczenia wolnego” przestaje mieć znaczenie, gdyż „wolne” mogłoby być jedynie „tłumaczenie, które odbiega od myśli tekstu, zawierając błędy, opuszczenia bądź nadinterpretacje”, a w jego miejsce pojawia się „odnosząca się do wypowiedzenia dokładność w tłumaczeniu” (Stolze 2009: 354). Dlatego też:

tłumaczyć znaczy formułować na nowo zrozumiane przez nas wypowiedzenie, przy czym podstawowe znaczenie ma tu nieskrępowana strukturami syntaktycznymi językowa wolność. W opozycji do niej stoją ograniczenia wynikające choćby $\mathrm{z}$ utrwalonych ekwiwalencji terminologicznych, standardowych formuł, norm obowiązujących w wypadku określonych rodzajów tekstu itp. Zakładająca kreatywność swoboda poszukiwania odpowiednich sformułowań w języku docelowym zyskuje na znaczeniu zwłaszcza wtedy, gdy ze względu na różnice kulturowe mamy do czynienia z odmiennym tłem rozumienia tekstu wyjściowego, co sprawia, że tekst ten w procesie tłumaczeniowym musi ulec przekształceniu (Stolze 2009: 354-355).

Reasumując, podkreślmy raz jeszcze, iż tłumaczenie wierszy Norwida jest bez wątpienia nie lada zadaniem: „właściwości jego sztuki poetyckiej stawiają wielkie wymagania tłumaczowi (...) i jeżeli niekiedy jego tekst podawany w języku francuskim wyda się zamącony lub ciemny, pamiętać wypada, że pewna ciemność mowy była właściwością samego Norwida. Tłumacz zdradziłby ducha poezji Norwida, gdyby usiłował tę ciemność rozjaśnić” (Wyka 1974: 8). Niezaprzeczalnie dzieło przekładowe Konopki, przedstawione w tym tekście jedynie na małym wycinku przykładowym - w postaci kilku wierszy Norwida przetłumaczonych na język francuski, może poświadczać, że tłumacz, zgodnie z cytowanymi powyżej słowami Stolze, jest również twórcą, a przełożony przez niego tekst jest tworem autonomicznym, tekstem istniejącym na równi z oryginałem. Pytanie tylko, czy wobec powyższych konkretnych przykładów przełożonych fragmentów wierszy nie można zaryzykować stwierdzenia, że w tych konkretnych przypadkach Konopka, wbrew intencji Norwida, „rozjaśnia” i „doprecyzowuje” jego poezję. Niewątpliwie można „bronić” tłumacza i twierdzić, że część jego wyborów językowych jest spowodowana koniecznością doboru rymów w języku francuskim, ale wyda- 
je się, że nie sposób usprawiedliwić tym faktem wszystkich jego świadomych decyzji przekładowych.

\section{Literatura}

Berman A., 2009, Przekład jako doświadczenie obcego, tłum. U. Hrehorowicz, [w:] Współczesne teorie przekładu. Antologia, P. Bukowski, M. Heydel (red.), s. 247-264.

Brajerska-Mazur A., 2004, Norwid w tłumaczeniach Jerzego Pietrkiewicza, „Pamiętnik Literacki”, 95(1), s. 151-174.

Bukowski P., Heydel M., 2009, Przekład - język - literatura, [w:] Współczesne teorie przekładu. Antologia, P. Bukowski, M. Heydel (red.), Kraków, s. 5-37.

Bukowski P., Heydel M. (red.), 2009, Współczesne teorie przekładu. Antologia, Kraków.

Gadamer H.-G., 2000, Estetyka i hermeneutyka, [w:] Rozum, słowo, dzieje. Szkice wybrane, H.-G. Gadamer, wyb., oprac. i wstęp K. Michalski, tłum. M. Łukasiewicz i K. Michalski, Warszawa, s. 135-136.

Gadamer H.-G., 2009, Lektura jest przekładem, [w:] Współczesne teorie przekładu. Antologia, P. Bukowski, M. Heydel (red.), Kraków, s. 321-325.

Gadamer H.-G., 2003, Prawda i metoda, tłum. B. Baran, Kraków.

Grondin J., 2007, Wprowadzenie do hermeneutyki filozoficznej, tłum. L. Łysień, Kraków.

Feliks Konopka w rocznicę śmierci, Centrum Polonii. Ośrodek Kultury, Turystyki i Rekreacji w Brniu, http://centrumpolonii.pl/wydarzenia-z-polski-czytnik/items/401.html (dostęp: 7.01.2019).

Halkiewicz-Sojak G., 2010, Nawiązane ogniwo. Studia o poezji Cypriana Norwida i jej kontekstach, Torun.

Hartman J. (red.), 2009, Słownik filozofii, Kraków.

Kopaliński W., 1983, Słownik wyrazów obcych i zwrotów obcojęzycznych, Warszawa.

Korpysz T., Puzynina J., Subko B., Teleżyńska E., 2016, Norwid i my... O Pracowni Słownika Języka Cypriana Norwida, Kraków.

Markowski M. P., 1996, Nietzsche i hermeneutyka, „Teksty Drugie”, 1(37), s. $20-41$.

Norwid C. K., 1974, Wybór poezji. Choix de poèmes, tłum. F. Konopka, Kraków-Wrocław.

Nowak Z. J., 1991-1992, Jeszcze jeden kontekst do „Fatum” Norwida, „Studia Norwidiana", 9-10, s. 125-131. 
Płaszczewska O., 2018, Włoskie przekłady poezji Norwida, „Studia Norwidiana”, 36, https://ruj.uj.edu.pl/xmlui/bitstream/handle/item/61425/ plaszczewska_wloskie_przeklady_poezji_norwida_2018.pdf?sequence=1\&isAllowed $=y$ (dostęp: 10.02.2019).

Pniewski D. (red.), 2012, Jedno dzieło - wiele interpretacji. Rozważania nad „Wielkimi słowami” Cypriana Norwida, Toruń.

Przyłębski A., 1995, Oblicza hermeneutyki, Poznań.

Puzynina J., 1990, Słowo Norwida, Wrocław.

Puzynina J., 2006, Słowo poety, Warszawa.

Puzynina J. (red.), Studia nad językiem Cypriana Norwida, Warszawa.

Puzynina J., Subko B., 1998, Les traductions françaises de la poésie de Cyprian Norwid, [w:] La littérature polonaise en France, M. Laurent en la collab. avec L. Dyèvre (red.), Lille, s. 151-164.

Ricœur P., 1989, Język, tekst, interpretacja. Wybór pism, tłum. P. Graff, K. Rosner, Warszawa.

Ricœur P., 1989a, Hermeneutyczna funkcja dystansu, tłum. P. Graff, [w:] tenże, Język, tekst, interpretacja. Wybór pism, P. Ricœur, Warszawa, s. 224-245.

Ricœur P., 1989b, Przyswojenie, tłum. P. Graff, [w:] tenże, Język, tekst, interpretacja. Wybór pism, Warszawa, s. 272-289.

Ricœur P., 1989c, Zadanie hermeneutyki, tłum. P. Graff, [w:] tenże, Język, tekst, interpretacja. Wybór pism, Warszawa, s. 191-223.

Ricœur P., 1989d, Zakończenie, tłum. K. Rosner, [w:] tenże, Język, tekst, interpretacja. Wybór pism, Warszawa, s. 180-187.

Ricour P., 2004, Sur la traduction, Paris.

Ricœur P., 2009, Paradygmat przekładu, [w:] Współczesne teorie przekładu. Antologia, P. Bukowski, M. Heydel (red.), tłum. M. Kowalska, Kraków, s. 357-370.

Rosner K., 1991, Hermeneutyka jako krytyka kultury. Heidegger, Gadamer, Ricœur, Warszawa.

Sarnowski S., 1985, Świadomość i czas. O początkach filozofii współczesnej, Warszawa.

Scholz J., 1999-2000, Nowy przekład Norwida na język niemiecki, „Studia Norwidiana", 17-18, s. 363-373.

Skrendo A., 2010, Szczególny rodzaj nieprzekładalności. O pewnym kłopocie z zakresu teorii przekładu z nieustannym odwołaniem do hermeneutyki, „Teksty Drugie”, 4, s. 180-196.

Stolze R., 2009, Tłumaczenie jako proces ewolucyjny, [w:] Współczesne teorie przekładu. Antologia, P. Bukowski, M. Heydel (red.), tłum. P. Bukowski, Kraków, s. 347-355. 
Tomaszkiewicz T., 2016, Coraz bardziej interdyscyplinarny charakter badań przekładoznawczych, „Między oryginałem a przekładem”, 22: Przekład sceniczny: dramat, opera, piosenka, s. 45-61.

Tomaszkiewicz T., 2016, Présence du traducteur dans le processus de traduction spécialisée, „Studia Romanica Posnaniensia”, 43(1), s. 93-107.

Wesołowska M., 2014, Tłumaczenie a interpretacja: kilka uwag o „Szalonej lokomotywie" Stanisława Ignacego Witkiewicza w przekładzie na język angielski, „Rocznik Komparatystyczny”, 5, s. 453-468.

Wuthenow R. R., 1969, Das fremde Kunstwerk. Aspekte der literarischen Übersetzung, Göttingen.

Wyka K., 1974, Wstęp. Introduction, [w:] Wybór poezji. Choix de poèmes, C. K. Norwid, tłum. F. Konopka, Kraków-Wrocław, s. 6-11.

\section{The significance of hermeneutics in translation studies. A bunch of thoughts about translation of selected poems by Cyprian Kamil Norwid into French \\ Summary}

The objective of this paper is to apply the hermeneutics theory in translation. The author defines the notion of hermeneutics and presents briefly the main considerations of most prominent hermeneutic scholars. In this paper the relationship between hermeneutics and translation is presented on the example of Feliks Konopka, the author of French translation (1974) of selected fragments of Cyprian Kamil Norwid's poetry.

Keywords: hermeneutics, interpretation, translation, poetry, French, Cyprian Kamil Norwid 